\title{
Mortality of Oryzophagus oryzae (Costa Lima, 1936) (Coleoptera: Curculionidae) and Spodoptera frugiperda (J E Smith, 1797) (Lepidoptera: Noctuidae) Larvae Exposed to Bacillus thuringiensis and Extracts of Melia azedarach
}

\author{
Diouneia Lisiane Berlitz ${ }^{*}$, Aline Oliboni de Azambuja ${ }^{1}$, Alessandra Sebben ${ }^{1}$, Jaime Vargas \\ de Oliveira $^{2}$ and Lidia Mariana Fiuza ${ }^{1,2}$ \\ ${ }^{1}$ Laboratorio de Microbiologia e Toxicologia; Centro de Ciências da Saúde; Universidade "Vale do Rio dos \\ Sinos"; Av. Unisinos, 950; C.P.: 275; 93022-000; São Leopoldo - RS - Brasil. ${ }^{2}$ Estação Experimental do Arroz; Av. \\ Bonifácio Carvalho Bernardes, 1494; 94930-030; Cachoeirinha - RS - Brasil
}

\begin{abstract}
Oryzophagus oryzae (Costa Lima 1936) (Coleoptera: Curculionidae) and Spodoptera frugiperda (J E Smith, 1797) (Lepidoptera: Noctuidae) cause important crop losses in southern Brazil. Control is possible by the use of the bacteria Bacillus thuringiensis and extracts of Melia azedarach. This study aimed to evaluate the mortality, in vivo, of $\mathrm{O}$. oryzae and $\mathrm{S}$. frugiperda submitted to two isolates of $\mathrm{B}$. thuringiensis and the aqueous extract of $\mathrm{M}$. azedarach.

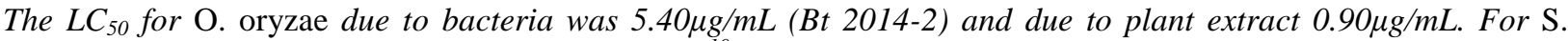
frugiperda, the Bt 1958-2 bacterial suspension $\left(1.10^{10} \mathrm{UFC} / \mathrm{mL}\right)$ caused a $100 \%$ of corrected mortality, showing that the purified Cry proteins caused a $C L_{10}$ of $268 \mu \mathrm{g} / \mathrm{mL}$ five days after the treatments, and $\mathrm{M}$. azedarach toxins caused a $C L_{50} 173 \mu \mathrm{g} / \mathrm{mL}$ four days after the treatment. Corrected mortality for $\mathrm{O}$. oryzae and $\mathrm{S}$. frugiperda in the interaction between the bacterial and plant toxins were 11 and $6 \%$, respectively. In the PCR analysis of $\mathrm{B}$. thuringiensis isolates, DNA fragments were enlarged and corresponded to the cryl and cry2 genes for Bt 1958-2. Thus, it could be concluded that the usage of Bt 2014-2 active against O. oryzae larvae; Bt 1958-2 for S. frugiperda and, for both the insect species, M. azedarach aqueous extract could be used.
\end{abstract}

Key words: Alternative pest control, entomopathogenic bacteria, insecticidal activity, botanical insecticidal

\section{INTRODUCTION}

Twelve million tons of rice, Oryza sativa (Linnaeus) were produced in Brazil in 2010, much of which in the south region, where average productivity was $6,412 \mathrm{~kg} \mathrm{ha}^{-1}$. The highest productivity is in the State of Rio Grande do Sul with $6,410^{-1}$ (Conab 2010). Losses due pests are often large, if untreated. The rice water weevil Oryzophagus oryzae (Costa Lima) (Coleoptera: Curculionidae) is an important pest in rice crops.
Its larvae attack the roots, causing losses up to 30\% (Martins et al. 1993; Sosbai 2010). Another important pest in rice crops is the fall armyworm, Spodoptera frugiperda (J E Smith) (Lepidoptera: Noctuidae) that can cause grain losses of up to 24\% (Cesconetto et al. 2005).

The control of these pests is mainly by the use of chemical pesticides that, in addition to killing the target species, affect the natural enemies, cause intoxication of producers and can leave residues in the environment. Alternatives to chemical controls

*Author for correspondence: dberlitz@hotmail.com 
are very important, such as microbial control with Bacillus thuringiensis (Berliner) and botanical pesticides as those found in Melia azedarach (Linnaeus) are promising. B. thuringiensis is a Gram-positive bacterium that yields crystals during the sporulation and made up by proteins synthesized by cry genes (Höfte and Whiteley 1989; Schenpf et al. 1998; De Maagd et al. 2001; Crickmore 2005). This entomopathogen has an insecticidal spectrum for more than 10 insect orders, including coleopteran and lepidopteran, according to the presence of cry genes and the proteins synthesized in the isolates (Schenpf et al. 1998; De Maagd et al. 2003).

The use of plant extracts with insecticidal activity is increasingly important in alternative pest control. For example, M. azedarach (Meliaceae), or Chinaberry has insecticidal properties (Huang et al. 1996, Ventura and Ito, 2000; Brunherotto and Vendramim 2001) due to various compounds, such as salanalin, meliaterin, and meliacarpinin. Some other compounds from this plant have insecticidal activity against beetles (Curculionidae, Tenebrionidae, and Chrysomelidae), as well as Lepidoptera (Huang et al. 1996; Bohnenstengel et al. 1999; Carpinella et al. 2003; Charleston et al. 2006; Nathan 2006).

The objective of this study was to assess the toxicity using in vivo assays of two new isolates of $B$. thuringiensis Cry proteins and an aqueous extract of $M$. azedarach as possible control agents for the rice pests $O$. oryzae and $S$. frugiperda.

\section{MATERIAL AND METHODS}

\section{Bacillus thuringiensis}

\section{Isolates origin and preparation}

The Bt 2014-2 and Bt 1958-2 isolates were isolated from the soil samples in rice growing areas in the State of Rio Grande do Sul. The first isolated was used because it had insecticidal activity against $O$. oryzae (Pinto and Fiuza 2003). The latter isolate was grown in the USUAL $+\mathrm{G}$ medium at $180 \mathrm{rpm}$ and $28^{\circ} \mathrm{C}$ for $48 \mathrm{~h}$ (De-Barjac and Lecadet 1976). Then the bacterial suspension was centrifuged at $5000 \mathrm{rpm}$ and cells were counted using Neubauer chamber and optical microscopy, and the concentration was adjusted to $1.10^{10} \mathrm{UFC} / \mathrm{mL}$.

\section{Cry proteins purification}

Proteins were obtained from the isolates (Bt 20142 and $B t$ 1958-2), grown in the USUAL+G medium, up to $90 \%$ of cell lysing as estimated using phase contrast microscopy. Protein purification was carried out through the sucrose gradient (67 and 79\%) in a refrigerated centrifuge $\left(82,700 \mathrm{~g}, 4^{\circ} \mathrm{C}, 1 \mathrm{~h}\right)$, where bands were separated and collected from the gradient from which proteins were dissolved in alkaline-buffer $(\mathrm{pH} 10)$ (Fiuza 1995). Bacterial protein dosages followed Bradford (1976).

\section{Detection of cry genes through PCR}

The $B t$ 1958-2 isolate was grown in Agar Nutrient at $30^{\circ} \mathrm{C}$ for $12 \mathrm{~h}$, after which total DNA extraction was carried out following Hansen and Hendriksen (2001) primers were used for that isolate, which enlarged the fragments of classes of cryl and cry 2 genes; the PCR analyses were performed according to description of Ben-Dov et al. (1997).

Reactions were carried out in a final volume of 25 $\mu \mathrm{L}$ with $5 \mu \mathrm{L}$ DNA added to the reaction buffer, to which $0.2 \mathrm{mM}$ from each dNTP, $0.2-0.5 \mathrm{mM}$ from each primer and $0.5 \mathrm{U}$ from Taq DNA polymerase were added. The amplification was performed in thermocyclator (PTC -100, MJ Research, Inc.) and a 35-cycle program for each reaction. In each cycle, the samples were denatured for $1 \mathrm{~min}$ at $94^{\circ} \mathrm{C}$ and ringed to the primers for $40-50$ seconds at $57^{\circ} \mathrm{C}$ after which extension of PCR products was carried out at $72^{\circ} \mathrm{C}$ for 50-90s. For the positive control $B$. thuringiensis aizawai HA3 was used, and the negative control was similarly prepared without the addition of DNA. The enlargement byproducts were analysed in agarose gels at $1.5 \%$, bleached in ethidium bromide, photographed under UV and compared with the molecular weight marker 100pb (Invitrogen $\left.{ }^{\circledR}\right)$.

\section{Toxins from Melia azedarach extracts}

For the extraction of toxins from the plants of $M$. azedarach, leaves were collected from the branches $3-4 \mathrm{~m}$ above the ground in October (2004) at UNISINOS, and were dried at $40{ }^{\circ} \mathrm{C}$ during $48 \mathrm{~h}$. Ten grams of dried product was crushed and mixed in $100 \mathrm{~mL}$ sterile distilled water (10\% aqueous extract) at $4^{\circ} \mathrm{C}$ following Bradford (1976). 


\section{Target Insect Pests}

Oryzophagus oryzae - rice water weevil

Second and third instars of $O$. oryzae were collected from rice paddy in the Rice Experimental Station of Instituto Riograndense do Arroz (IRGA) in Cachoeirinha, RS and kept in assay tubes and glass basins with water and rice plants in a B.O.D chamber with temperature, relative humidity and photoperiod controlled $\left(28 \pm 2{ }^{\circ} \mathrm{C}, 75 \pm 2 \% \mathrm{RH}\right.$ and a $12 \mathrm{~h}$ photo phase).

\section{Spodoptera frugiperda - fall armyworm}

Second instar caterpillars of S. frugiperda were collected from the corn fields in Novo Hamburgo, RS, and maintained on Poitout artificial diet (Poitout and Bues 1970) under the controlled conditions at $28 \pm 2{ }^{\circ} \mathrm{C}, 75 \pm 2 \% \mathrm{RH}$, and a $12 \mathrm{~h}$ photo phase.

\section{Bioassays with target insects \\ Oryzophagus oryzae}

The experimental protein concentrations were determined through a pilot assay with the bacterial and plant toxins, using five dilutions from 0.5 to $34 \mu \mathrm{g} / \mathrm{mL}$ for $B$. thuringiensis and 0.025 to 257 $\mu \mathrm{g} / \mathrm{mL}$ for $M$. azedarach. The Lethal Concentration (LC) was determined in sterile assay tubes with $1 \mathrm{~mL}$ protein solution and disinfected rice plant, into which 5 larvae of $O$. oryzae were added. Three replicas using 20 insects/treatment resulted in 720 insects tested. In the controls, proteins were substituted by the sterile distilled water. Assays were kept under controlled conditions $\left(28 \pm 2{ }^{\circ} \mathrm{C}, 75 \pm 2 \% \mathrm{RH}, 12 \mathrm{~h}\right.$ photo phase) and the mortality was quantified seven days later.

In the assays for the interaction of bacterial and plant toxins, $\mathrm{LC}_{50}$ of $B$. thuringiensis and $M$. azedarach were used to determine the experimental concentrations and mixed 1:1 (v/v). Assays were carried out as described above.

\section{Spodoptera frugiperda}

For the $1.10^{10} \mathrm{UFC} / \mathrm{mL}$ suspension assay, individual second instar $S$. frugiperda caterpillars were kept on acrylic miniplates (35 mm wide) with artificial diet containing $100 \mu \mathrm{L}$ of bacterial suspensions. Pilot assay protein concentrations ranged from 0.36 to $3.608 \mu \mathrm{g} / \mathrm{mL}$ for $M$. azedarach, and from 0.028 to $281 \mu \mathrm{g} / \mathrm{mL}$ for $B$. thuringiensis. Individual caterpillars of $S$. frugiperda were kept on acrylic miniplates with a rice-leaf disc $(10 \mathrm{~mm})$ containing $10 \mu \mathrm{L}$ of each treatment tested. In the control, sterile distilled water was used instead of bacterial suspensions. The treatments comprised 30 insects/concentration and three replicas each for a total of 1080 insects. Bioassays were done at $28 \pm 2{ }^{\circ} \mathrm{C}, 75 \pm 2 \%$ relative humidity and $12 \mathrm{~h}$ photo phase. Leaf discs were substituted by the artificial diet $48 \mathrm{~h}$ after the treatment. The mortality was quantified daily for seven days after the treatment.

For the interactions of bacteria and plants, the $M$. azedarach $\mathrm{LC}_{50}$ was used as $1.10^{5} \mathrm{UFC} / \mathrm{mL}$ for $B$. thuringiensis, mixed 1:1 (v/v), and assays followed the procedures described above.

\section{Statistical Analysis}

Corrected mortality (CM) was estimated following Abbott (1925). Lethal Concentration (LC) and Lethal Time (LT) were estimated with Probit Analysis using the program Polo-PC LeOra 1987 (Haddad 1998). Mortality was compared among the treatments with the analysis of variance ANOVA and Tukey $(\alpha=0.05)$ using Systat program.

\section{Protein assessment in SDS-PAGE}

Isolate suspensions and proteins and aqueous extract of $M$. azedarach were analyzed for the proteic profile in poliacrilamid gel at $10 \%$, following Laemmli (1970). Protein bands were compared to the molecular weight marker (Invitrogen ${ }^{\circledR}$ ) using Kodak Digital Science 1D program.

\section{RESULTS AND DISCUSSION}

The mortality of $S$. frugiperda and $O$. oryzae with the purified protein is shown in Table I. This showed higher mortality of $O$. oryzae by $B$. thuringiensis purified proteins in comparison with the control $(F=4.43, \mathrm{P}=0.008)$. Therefore, as apparently $O$. oryzae has not been studied with respect to $B$. thuringiensis purified proteins, these results seemed promising for its control with this bacteria. Similar results were also found with the botanical extract $(F=8.92, \mathrm{P}=0.0001)$. However, these results were in contrast of those for the curculionid Premnotrypes vorax (Hustache) (Uribe et al. 2003), in which none of the extracts with the genes cry 1, cry 3, cry 7 or cry 8 were effective. 
Table 1 - Lethal Concentration (LC) of the Cry proteins of Bacillus thuringiensis Cry proteins and aqueous extract of Melia azedarach evaluated against Oryzophagus oryzae and Spodoptera frugiperda larvae.

\begin{tabular}{|c|c|c|c|}
\hline Insects & & $\begin{array}{l}\text { Lethal Concentration of the Cry proteins of } \\
\text { B. thuringiensis }(\mu \mathrm{g} / \mathrm{mL})(\mathrm{IC} 95 \%: \mathrm{Il}-\mathrm{SI})\end{array}$ & $\begin{array}{l}\text { Lethal Concentration of } M \text {. } \\
\text { azedarach }(\mu \mathrm{g} / \mathrm{mL})(\mathrm{IC} 95 \%: \mathrm{Il}-\mathrm{SI})\end{array}$ \\
\hline \multirow{4}{*}{ O. oryzae } & $\mathrm{LC}_{10}$ & $0.35(0.028-1.15)$ & $0.00045(0-0.026)$ \\
\hline & $\mathrm{LC}_{50}$ & $5.4(1.86-11.63)$ & $0.90(0.08-9.07)$ \\
\hline & $\mathrm{LC}_{70}$ & $15.0(6.81-39.06)$ & $78.620(7.1-8,920)$ \\
\hline & $\mathrm{LC}_{10}$ & $268.3(51.9-19,111)$ & $3.55(0.004-23.32)$ \\
\hline \multirow[t]{2}{*}{ S. frugiperda } & $\mathrm{LC}_{50}$ & ND & $173(28.37-1,397)$ \\
\hline & $\mathrm{LC}_{70}$ & ND & $847(187.59-43,058)$ \\
\hline
\end{tabular}

IC - Interval Confidence: $\mathrm{Il}$ = inferior limit; $\mathrm{Sl}$ = superior limit; $\mathrm{ND}=$ value not determined.

The extracts of $M$. azedarach were tested against different beatle species (Carpinella et al. 2003). Doses of $2 \mathrm{mg} / \mathrm{cm}^{3}$ were used for Sitophylus oryzae (Linné, 1763) (Coleoptera: Curculionidae) and Priocyphus bosqui (Hustache) (Coleoptera: Curculionidae), and doses of $0.4 \mathrm{mg} / \mathrm{cm}^{3}$ for Pantomorus leucoloma, (Boheman, 1840) (Coleoptera: Curculionidae), which inhibited their feeding within $24 \mathrm{~h}$ after the treatment. The mortality of adults and larvae of the Gonipterus scutellatus (Gyllenhal) (Coleoptera: Curculionidae), a herbivore on Eucaliptus sp., after azadiractin ingestion was $73 \%$. However, $B$. thuringiensis kurstaki did not affect the larvae and adults mortality (Santolamazza-Carbone and AnaMágan 2004).

Corrected mortality in $S$. frugiperda due to $B t$ 1958-2 isolate was high, yet when Cry proteins were purified, the isolates had no insecticidal activity $(F=2.40, \mathrm{P}=0.99)$ against the leaf caterpillar, with an $\mathrm{LC}_{10}$ of $268 \mu \mathrm{g} / \mathrm{mL}$ within five days after the treatments (Table I). This low mortality with purified Cry proteins could be due to the resistance mechanisms, including the changes in allele frequencies of specific genes (Heckel et al. 2007), or the production of other $B$. thuringiensis toxins. Among the latter are "Vip" proteins, in which the "Vip3A" is important due to its toxic effects on Lepidoptera, including $S$. frugiperda (Schnepf et al. 1998; De Maagd et al. 2003). Testing five-strain supernatant of $B$. thuringiensis against the fall armyworm, Barreto et al. (1999) found mortality between 65-90 \% caused by "Vip" proteins. Thus, mortality due to the bacteria could be higher than that due to Cry proteins alone. The criteria to determine the insect specificity in the case of VIPs are not completely understood (Bhalla et al. 2005).

The entomopathogen includes other virulent factors, such as beta-exotoxins, alfa-exotoxins, hemolysins, enterotoxins, chitinases, and phospholipases (Höfte and Whiteley 1989; De Maagd et al. 2003). However, the real role of each factor in bacterium virulence is still unknown and so it is difficult to understand the toxic spectra of the isolates that synthesize more than one protein. To completely understand the resistance of $B$. thuringiensis, it is necessary to complement the results with the studies about biochemistry and physiology of target insect (Heckel et al. 2007). The $\mathrm{CL}_{50}$ of $173 \mu \mathrm{g} / \mathrm{mL}$ of $S$. frugiperda in the extract of $M$. azedarach was after four days of the treatment $(F=21.52, \mathrm{P}=0.0001)$ and action could be due to its influence on feeding and behavior (Carpinella et al. 2003). Breuer et al. (2003) found a decrease of $31 \%$ in the activity of C cholinesterase in S. frugiperda, when the extract of $M$. azedarach $(0.01 \%)$ was mixed in the artificial diet. Similarly, three new meliacarpin compounds from of the leaves against $S$. litorallis (Boisduval, 1833) (Lepidoptera: Noctuidae), showed a $\mathrm{LC}_{50}$ of 2.36; 1.19 , and $0.48 \mathrm{ppm}$ for the compounds 1,2 , and 3, respectively, when compared with $0.32 \mathrm{ppm}$ for azadiractin (Bohnenstengel et al. 1999).

The mortality of $S$. frugiperda was due to the compounds such as meliacarpin and its byproducts aqueous extract from $M$. azedarach. Also, Chinaberry leaves at 5\% extract, resulted in $>$ 90\% mortality in Tuta absoluta (Meyrick, 1917) (Lepidoptera: Gelechiidae) (Brunherotto and Vendramim 2001). The aqueous extract of $M$. azedarach together with Neemix $4.5^{\circledR}$ was effective in the control of Plutella xilostella (Linné, 1758) (Lepidoptera: Plutelidae) (Charleston et al. 2006).

Corrected mortality (ca. $11 \%$ in $O$. oryzae, $F=$ $0.76, \mathrm{P}=0.588$ ) in the simultaneous application of bacterial and plant toxins was similar to that of the controls (Fig. 1). Corrected mortality was $6 \%$ in $S$. frugiperda and therefore also similar to that of controls $(F=0.52, \mathrm{P}=0.754)$. These results suggested antagonism when Cry proteins of $B$. 
thuringiensis were used with the aqueous extract of $M$. azedarach. The ether extract from the Chinaberry leaves had a powerful antimicrobial activity against $B$. cereus (Marquez et al. 2003). In contrast, assays using a combination of Taxodium distichum and B. thuringiensis increased the mortality in stored-grain pests (Sabbour 2003).

The fragments of cry 1 and $c r y 2$ gene classes were found in PCR analysis of the $B t$ 1958-2 isolate (Fig. 2). Also, the fragments of cry3 class have been found in Bt 2014-2 isolates (Pinto and Fiuza 2003). It is known that cry3, cry 7 , and cry 8 gene classes synthesize the proteins with insecticidal activity for the Coleoptera and cry 1 and cry 2 gene classes synthesize the proteins with insectidal activity for Lepidoptera (De Maagd et al. 2003).

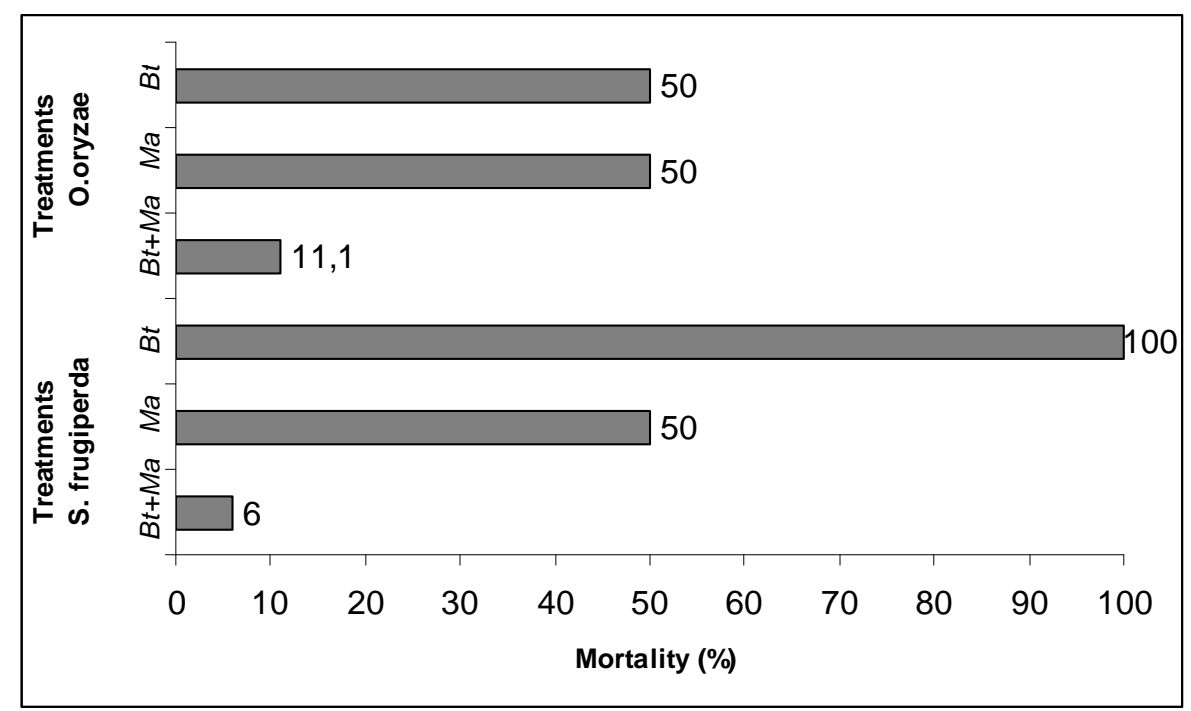

Figure 1 - Corrected mortality of the Oryzophagus oryzae and Spodoptera frugiperda larvae treated with Bacillus thuringiensis isolates (Bt) and Melia azedarach aqueous extract (Ma).

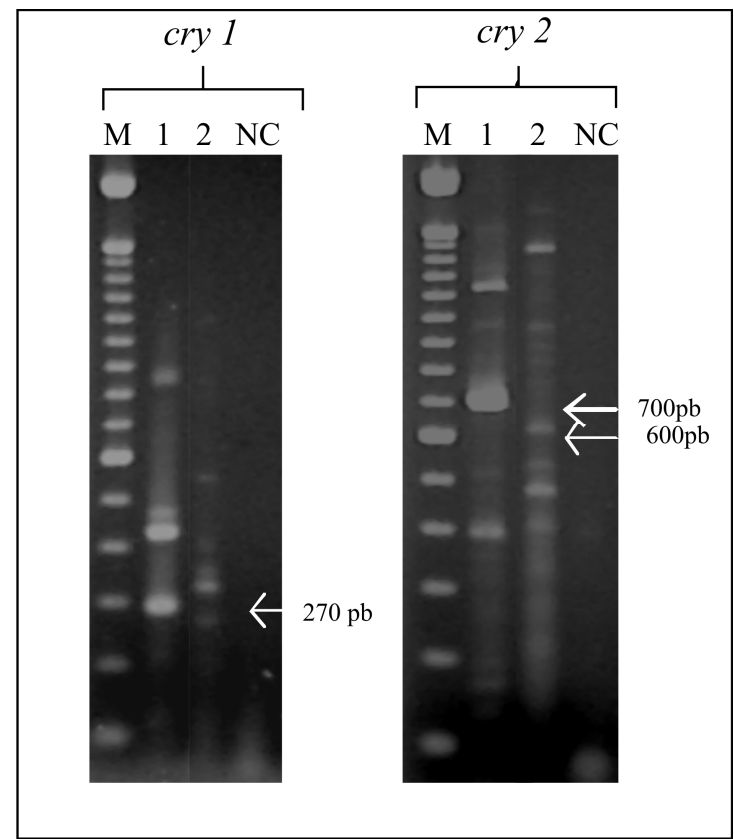

Figure 2 - Agarose gels (1.5\%) of PCR products amplified. (M) Molecular Marker 100pb (Gibco BRL), arrows indicated the molecular weight; (NC) Negative Controls; (1) Bt aizawai HA3; (2) Bt 1958-2. 
The assessment of the profile of Cry $B$. thuringiensis proteins and $M$. azedarach aqueous extract in polyacrilamide gel (10\%) showed predominant bands of $209 \mathrm{kDa}$ for the proteins of Bt 2014-2 and Bt 1958-2 isolates, and 50kDa for the plant insecticide (data not shown).

In the light of few information for controlling $O$. oryzae with $B$. thuringiensis and $M$. azedarach, the present results suggested that this pests could be effectively controlled with these alternative extracts. Thus, field trials should be done to test how these extracts could be applied and field mortality rates should be estimated. This could be an important first step in establishing their use in the management of rice culture pests. Additionally, the genes of the subclass isolates of B. thuringiensis should be examined because they might provide control for the larvae of $O$. oryzae that live in the water and is difficult to control by the standard methods (pulverized chemical pesticides). This could be a better option to systemic insecticides that, in addition to be left out in the soil and water, could also be found in the rice grains in traces.

As for $S$. frugiperda, studies have concentrated on the use of new isolates of $B$. thuringiensis and cry genes with the insecticidal activities. A study of 58 subspecies of $B$. thuringiensis in $S$. frugiperda found that the caterpillar mortality was $80 \%$ (Polanczyk et al. 2003). Also, in a test of 77 entomopathogenic strains, only four isolates were toxic to the army caterpillar (Silva et al. 2004). This suggested any level of resistance by $S$. frugiperda to the entomopathogen and therefore more studies would be needed to address this issue, especially due to the importance of this polyphagous phytophagous pest.

The results showed that $B t 1958-2$ isolates were effective against $S$. frugiperda caterpillars and were potentially useful for its control, despite the low toxicity associated with the synthesized Cry proteins. Bt 2014-2 isolate or the purified Cry3 proteins could also be useful for the control of $O$. oryzae larvae. The aqueous extracts of $M$. azedarach was toxic to both the pests (O. oryzae and $S$. frugiperda) and had high potential as a botanical insecticide. Interestingly, the combined use of these two extracts reduced their toxic effects and so they should not be used together for the pest control.

\section{REFERENCES}

Abbott WS. A method of computing the effectiveness of inseticide. J. Econ. Entomol. 1925; 18: 265-267.

Bhalla R, Dalal M, Panguluri SK, Jagadish B, Mandaokar AD, Singh AK, Kumar PA. Isolation, characterization and expression of a novel vegetative insecticidal protein gene of bacillus thuringiensis. Fems microbiol letters. 2005; 243(2): 467-472.

Barreto MR, Louguercio LL, Valicente FH, Paiva E. Inseticidal activity of culture supernatants from bacillus thuringiensis berliner strains against spodoptera frugiperda (lepidoptera: noctuidae) larvae. An soc entomol brasil. 1999; 28: 675-685.

Ben-Dov E, Zaritsky A, Dahan E, Barak Z, Sinai R, Manasherob R, Khamraev A, Trotskaya E, Dubitsky A, Berezina N, Margalith Y. Extended screening by PCR for seven cry-group genes from field-collected strains of bacillus thuringiensis. App environ microbiol. 1997; 63: 4883-4890.

Bohnenstengel FI, Wray V, Witte L, Srivastava RP, Proksch P. Inseticidal meliacarpins (c-seco limnoids) from melia azedarach. Phytochem. 1999; 50: 977-982.

Bradford MM. A rapid and sensitive method for the quantification of microgram quantities of protein utilizing the principle of protein-dye binding. Anal biochem. 1976; 72: 248-254.

Breuer M, Hoste B, Loof A, Naqvi SNH. Effect of melia azedarach extract on the activity of nadphcytochrome c reductase and cholinesterase in insects. Pest biochem physiol. 2003; 76: 99-103.

Brunhetto R, Vendramim JD. Bioatividade de extratos aquosos de melia azedarach 1. Sobre o desenvolvimento de tuta absoluta (lepidoptera: gelechiidae) em tomateiro. Neot entomol. 2001; 30: 455-459.

Carpinella MC, Defago MT, Valladares G, Palacios SM. Antifeedant and inseticide proprieties of a limnoid from melia azedarach (meliaceae) with potential use for pest management. $J$ agricul chem. 2003; 51: 369-374.

Cesconetto AO, Fávero S, Oliveira AKM, Souza CC. Distribuição espacial e dano da lagarta do cartucho do milho, spodoptera furgiperda (je smith, 1797) em sidrolândia, mato grosso do sul. Ensaios. 2005; 9(2): 305-314.

Charleston DS, Kfir R, Dicke M, Vet EM. Impact of botanical extracts derived from melia azedarach and azadiracta indicate on populations of plutella xilostella and its natural enemies: a field test of laboratory findings. Bio. Control. 2006; 39: 105-114.

Conab - Companhia Nacional De Abastecimento 2010. Levantamento de grãos da safra 2010/11. 23 de novembro de 2010. Avaiable from http://www.conab.gov.br 
Crickmore N. Using worms to better understand how bacillus thuringiensis kills insects. Trends microbiol. 2005; 13: 347-350.

De-Barjac H, Lecadet MM. Dosage biochimique d'exotoxine thermostable de bacillus thuringiensis d'après i'nhibition d'arn-polymerases bacteriennes. $C$ r academic science. 1976; 282: 2119-2122.

De-Maagd Ra, Bravo A, Berry C, Crickmore N, Schnepf HE. Structure, diversity and evolution of protein toxins from spore-forming entomopathogenic bacteria. An rev genetics 2003; 37: 409-433.

De-Maagd RA, Bravo A, Crickmore N. How bacillus thuringiensis has evolved specific toxins to colonize the insect world. Trends genetic. 2001; 17: 193-199.

Fiuza LM. Estude des sites récepteurs et de la toxicité des delta-endotoxines de bacillus thuringiensis berliner chez les larves de la pyrale du riz chilo supressalis walker. França, 160 p. These de doctorat, escole national superieure agronomique de montpellier. 1995.

Haddad ML. Utilização do polo-pc para análise de probit. In: alves, s.b. Controle microbiano de insetos. Piracicaba, FEALQ, São Paulo, 1998. P. 999-1013

Hansen BM, Hendriksen NB. Detection of enterotoxic bacillus cereus and bacillus thuringiensis strain by PCR analysis. App environ microbiol. 2001; 67:185-189.

Heckel D, Gahan LJ, Baxter SW, Zhao JZ, Schelton AM, Gould F, Tabashinik BE. The diversity of bacillus thuringiensis resistance genes in species of lepidoptera. J. Invert. Pathol. 2007; 95: 192-197.

Höfte H, Whitheley R. Inseticidal crystal proteins of bacillus thuringiensis. Microbiol review 1989; 53: 242-255.

Huang RC, Tadera K, Yagi F, Minami Y, Okamura H, Iwagawa T, Nakatani M. Limnoids from melia azedarach. Phytochem. 1996; 43: 581-583.

Laemmli U. Cleavage of structural proteins during the assembly of the head of bacteriophage t4. Nature. 1970; 227:680-685.

Marquez BP, Cárdenas AO, Morales CR, Star MJ. Identificación de compuestos de melia azedarach, syzgium aromaticum y cinnamomum zeylanicum com efecto inhibitorio sobre bacterias y hongos. Ciencia uanl 2003; 3: 333-338.

Martins JFS, Terres ALS, Botton M. Alternativas de controle da bicheira-da-raiz visando um menor impacto ambiental. Lav arroz 1993; 46: 12-14.

Nathan SS. Effects of melia azedarach on nutritional physiology and enzyme activities of the rice leaffolder cnaphalocrocis medinalis (guenée) (lepidoptera:pyralidae). Pest biochem physiol. 2006; 84: 98-108.
Pinto LMN, Fiúza LM. PCR and bioassays screening of bacillus thuringiensis isolates from rice-fields os rio grande do sul, specific to lepidopterans and coleopterans. Braz j microbiol. 2003; 34: 305-310.

Poitout S, Bues R. Élevage de plusieurs espèces de lépidoptères noctuidae sur mitieu artificiel riche et sur milieu simplifié. Ann ecol animals 1970; 2: 79-91.

Polanczyk RA, Martinelli S, Omoto C, Alves SB. Bacillus thuringiensis no manejo integrado de pragas. Biotec ciên desenv. 2003; 31: 18-27.

Sabbour MM. Combined effects of some microbial control agents mixed with botanical extracts on some stored product insects. Pakistan j biol science. 2003; 6: $51-56$.

Santolamazza-Carbone S, Ana-Magán FJF. Testing of selected inseticides to assess the viavility of the integrated pest management of the eucalyptus snoutbeetle gonipterus scutellatus in north-west spain. Jen 2004; 128: 620-627.

Schnepf E, Crickmore N, Vanrie J, Baum J, Feitelson J, Zeigler DR, Dean DH. Bacillus thuringiensis and its pesticide crystal proteins. Microbiol. Mol biol review 1998; 62: 775-806.

Silva SMB, Silva-Werneck1 JO, Falcão R, Gomes AC, Fragoso RR, Quezado MT, Neto OBO, Aguiar JB, Sá MFG, Bravo A, Monnerat RG. Characterization of novel brazilian bacillus thuringiensis strains active against spodoptera frugiperda and other insect pests. J app entomol. 2004; 128: 102-107.

Sosbai- Arroz Irrigado: recomendações técnicas da pesquisa para o sul do brasil. Porto alegre, sosbai, 2010, 188 p.

Uribe D, Martinez W, Cerón J. Distribuition and diversity of cry genes in native strains of bacillus thuringiensis obtained from different ecosystems from colombia. J invert pathol. 2003; 82: 119-127.

Ventura MU, Ito M. Antifeedant activity of melia azedarach (1.) Extracts to diabrotica speciosa (genn.) (coleoptera: chrysomelidae) beetles. Braz arch biol tecnol. 2000; 43(2): 215-219.

Received: February 14, 2011; Revised: June 21, 2011; Accepted: June 05, 2012. 


\section{Página Em}

branco 